\title{
RIBA AND JUSTIFICATION IN PRACTICE IN SCHOLARS' VIEWS
}

\author{
Meirison \\ UIN Imam Bonjol Padang \\ meirisonn.a@gmail.com
}

Received :

; Accepted :

; Published :

\begin{abstract}
Efforts have long been focused on trying to explain and justify riba (Usury) and dozens of theories have emerged in this area. This approach went to some Islamic economics writers, who also tried to justify and interpret interest in accordance with the principles of Islamic economics. This is one of the most important economic topics in the past and present, and although the writings on some of the elements of this subject began about half a century ago, but the observer renewed the introduction of these views and ideas in different formats in the present era, Islamic economics issues only show a picture of this subject for discussion. Therefore, this discussion aims to collect these opinions and theories and evaluate them in order to present them to the new discussioners - with different scientific backgrounds - in a suitable manner that serves to discuss this subject and clarify the general framework for it. This discussion will focus briefly on the presentation of some of these theories, opinions and justifications and discuss the hypotheses of these views and theories.
\end{abstract}

Keywords: Riba, Justification

$$
\begin{aligned}
& \text { رد الأفضل والأكثر في القرض } \\
& \text { فرق بين مسألتين : قال مالك: إذا اقترض منه شيئا فردّ إليه أفضل جاز , وإن ردّ } \\
& \text { إليه أزيد منه لم يجز , ووفي كلا الموضعين وقد وجد الفضل }
\end{aligned}
$$

Pengembalian hutang dengan yang lebih bernilai

Membedakan antara kedua masalah, berkata Malik, apabila meminjam dari sesorang dan mengembalikannya dengan sesuatu yang lebih bernilai diperbolehkan akan tetapi menambah kuantitas tidak diizinkan. 


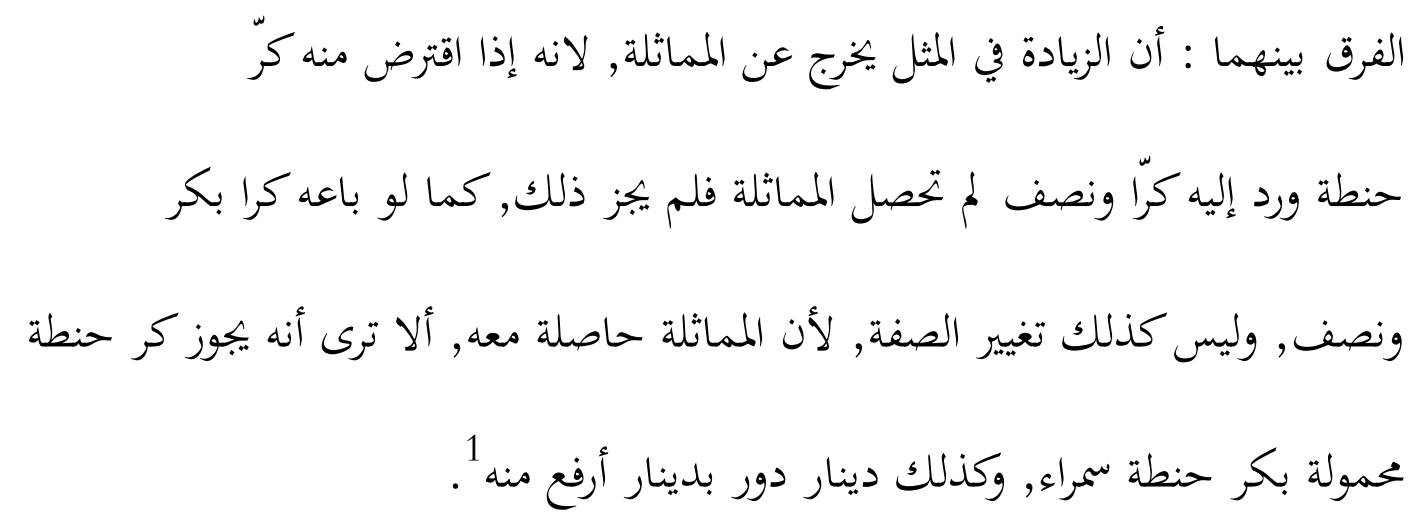

Perbedaan diantara keduanya adalah, penambahan kuantitas dalam jenis yang sama tidak lagi dinamakan kesetaraan, apabila dipinjam sekarung sekarung setengah maka tidak bisa dinamakan setara dan tidak diperbolehkan. Sebagaimana dijual sekarung dengan sekarung setengah. Perubahan pada sifat benda tersebut masih dianggap setera selama kuantitasnya tidak berubah, coba fikirkan ketika menukar sekarung gandum dengan sekarung gandum samra, begitu juga tukar menukar dinar yang lebih tinggi kualitasnya.

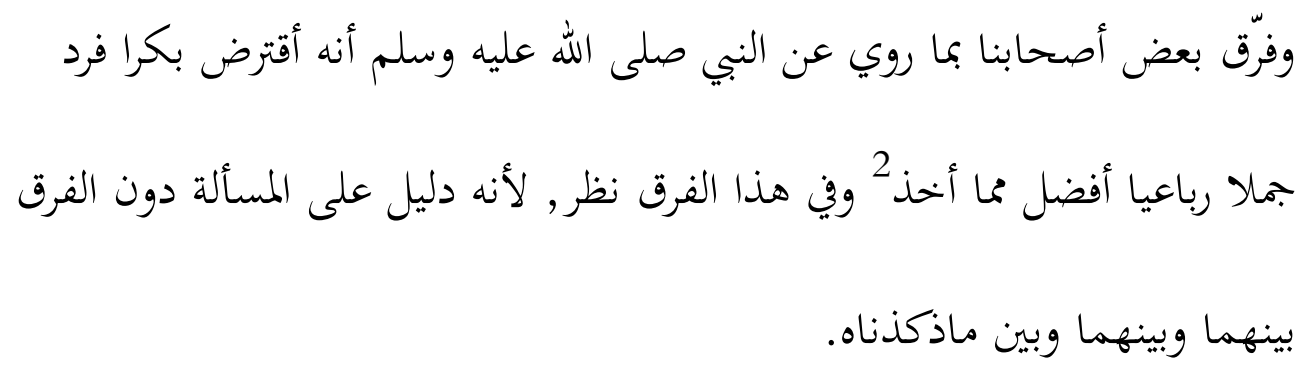

Para sahabat kami membedakan sesuai dengan apa yang dirawikan dari Nabi S.A.W, bahwa ia meminjam seekor onta yang berumur 3 tahun dan menggantikanya dengan onta yang berumur 6 tahun (memasuki 7 tahun), lebih baik dari yang dipinjam oleh beliau pertama kali.

\footnotetext{
${ }^{1}$ Imam Faqih al-Qadhiy Abi Muhammad Abdul Wahab bin Ali bin Nasr al-Baghdadi Furuq al-Fiqhiyah (Riyadh:Dar al-Buhuts li ad-Dirasat al-Islamiyah wa Ihya' at- Turats:1992),h.90

2

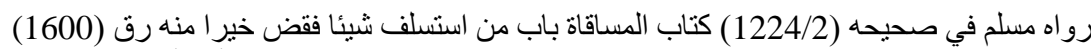

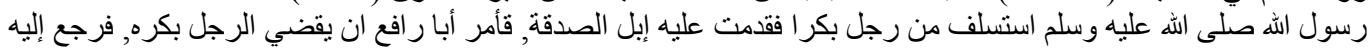

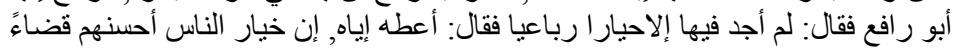


وفرق آخر: وهو أن التهمة بينهما تقوى في زيادة المثل دون الصفة, لأنه إذا دفع

كرا عن كر ونصف عن كراتهم بان يكون إنما أقرضه لاجل ذلك, وليس كذلك في زيادة

الصفة, لانه إذا دفع عن كر محمولة كر سمراء لم تقع التهمة في ذلك كما وقعت في زيادة المثل, فلذلك افترقا , والله أعلم

Kecenderungan terhadap riba lebih keras ketika terjadi penambahan kuantitas dan tidak pada kualitas, karena dia membayar sekarung dengan sekarung setengah, boleh jadi ia meminjamkan karena mengharapkan kelebihan, dan tidak pada penambahan kualitas pada waktu pengembalian pinjaman tersebut. Hal ini tidak didapatkan ketika sekarung mahmul ditukar dengan sekarung samra, karena tidak ada penambahan kuantitas oleh karena itu kedua perkara ini berbeda ${ }^{3}$.

$$
\text { وقو ومن أبي رافع أي مولى رسول الله قال استسلف رسول الله أي استقرض بكرا يفتح }
$$

Rasulullah meminjam seekor berumur tiga tahun, kemudian datang kepada Rasulullah ontah dari hasil sedekah (Zakat), dan ia meminta saya (Abi Rafi') untuk membayar dengan onta yang berumur tiga tahun, akan tetapi saya

${ }^{3}$ Ibid, hal.91 
tidak mendapatkan onta yang sepadan hanya ada seekor onta yang telah berumur 6 tahun (akan memasuki umur 7 tahun), berkata Nabi S.A.W "berikanlah kepada orang itu, sebaik-baik kamu adalah orang yang paling baik dalam membayar hutang!" ..

في شرح السنة فيه من الفقه جوازا استسالف الإمام للفقراء إذا رأى بهم خلة وحاجة ثم يؤديه من مال الصدقة إن كان قد أوصل إلى المساكين وفيه دليل على جواز استقراض الحيوان وثبوته في الذمة وهو قول أكثر أهل العلم وبه قال الشافعي رحمه الله ويف الحديث دليل على أن من استقرض شيئا يرد مثل ما اقترض سواء كان ذلك من ذوات القيم أو من ذوات الأمثال لأن الحيوان من ذوات القيم وأمر النبي برد المثل وفيه دليل على أن من استقرض شيئا فرد أحسن أو أكثر منه من غير شرطه كان محسنا ويحل ذلك للمقرض وقال النووي رحمه الله يجيوز للمقرض أخذ الزيادة سواء زاد في الصفة أو في العدد ومنهب مالك أن الزيادة في العلد منهى عنها وحجة أصحابنا عموم قوله فإن خحير الناس أحسنهم قضاء وفي الحديث دليل على أن رد الأجود في القرض أو الدين من السنة ومكارم الأخلاق وليس هو من قرض جر منفعة لأن المنهى عنه ما كان مشروطا في عقد القرض وفي الحديث إشكال وهو أن يقال كيف قضى من إبل الصدقة أجود من الذي يستحقه الغريم مع أن الناظر في الصدقات لا يجوز تبرعه منها والجواب أنه افترض لنفسه ثم اشترى في القضاء من إبل الصدقة بعيرا 


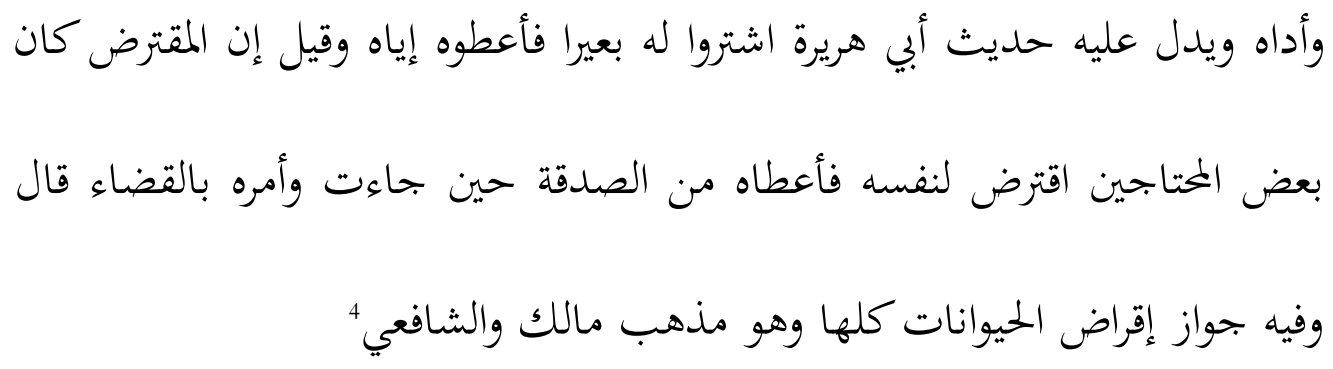

Dari keterangan sunnah diatas dapat diambil persepsi bahwa Imam boleh meminjam harta yang berasal dari zakat untuk membantu fakir/miskin apabila dibutuhkan, boleh meminjamkan hewan, inilah pendapat as-Syafi'i rahimahulah, hadits tersebut dapat dijadikan dalil, apabila seseorang meminjam sesuatu hendaklah dikembalikan sesuai dengan yang dipinjam baik dalam nilai atau dalam kuantitas (barang yang serupa) kerena hewan mempunyai nilai, nabi memerintahkan untuk mengembalikan hewan yang serupa dan diberikan jenis yang lebih baik atau lebih banyak dari pada yang beliau pinjam, tanpa ada persyaratan sebelumnya, ini adalah salah satu bentuk kemurahan (ihsan), hal ini dipebolehkan bagi orang yang meminjam kata an-Nawawi walaupun berlebih dalam kualitas maupun kuantitas. ${ }^{5}$ Akan tetapi mazhab Maliki melarang melebihkan kuantitas. Yang dijadikan hujjah oleh sahabat-sahabat kita bersifat umum yang mengatakan "sebaik-baik manusia adalah orang yang paling baik dalam membayar hutan". Mengembalikan hutan dengan yang lebih baik bukanlah termasuk kedalam hadits yang mekatakan pinjaman yang terdapat ekploitasi dalamnya maka ia adalah riba. Hal inilah yang dilarang, sebaimana tambahan tersebut disyaratkan terlebih dahulu sebelum meminjam. Dari hadits tersebut terdapat permasalahan, bisakah nazir membayarkan pinjaman pada orang yang menghutanginya dengan harta yang lebih baik dari yang dipinjam serta berasal dari zakat?, sedangkan sebenarnya nazir tidak boleh bersedekah dari harta zakat, jawabannya nazir meminjamnya dari harta tersebut, kemudian dibelilah seekor onta dan diserahkan kembali, sebagaimana yang disebutka dalam hadits Abu

\footnotetext{
${ }^{4}$ Maktabah Syamilay 9/367

${ }^{5}$ Al-Wakil, Muhammad bin Umar, al-Asybah wa an-Nazair bi Tahqiq (Kairo, Maktabar Rasyid, 1999),hal.343
} 
Hurairah, Nabi membeli onta kemudian ia menyerahkan onta tersebut, dikatakan, yang meminjam itu adalah orang lain yang membutuhkan kemudian dibayar dari harta zakat, diperbolehkan meminjam hewan dari harta zakat menurut Imam Malik dan Imam Syafi'iy.

$$
\begin{aligned}
& \text { وقال: \إن خياركم أحسنكم قضاء《); ولأنه لم بتعل تلك الزّيادة عوضاً في القرض، } \\
& \text { ولا وسيلة إليه، ولا إلى استيفاء حقّه، فحلت كما لو لم يكن قرض، بل إن الحنفية } \\
& \text { والشافعية نصِّا على أنه يستحبّ في حقّ المقترض أن يرد أجود مما أخذ بغير شرط، } \\
& \text { وأنه لا يكره للمقرض أخذه. }
\end{aligned}
$$

وذهب مالك إلى التفصيل في المسألة، فكره أن يزيد المقترض في الكمّم والعدد إلا في اليسير جداً، وقال: إنما الإحسان في القضاء أن يعطيه أجود عيناً وأرفع صفةً وأما أن يزيـده في الكيـل أو الوزن أو العـدد فـلا، وهـذا كلّه إذاكـان مـن غـير شـرط حـين السلف 6. وروي عن أحمد المنع من الزّيادة والفضل في القرض مطلقاً، وعن أبيّ بن كعب وابن عباس وابن عمر رضي الله عنهم أن المقرض يأخذ مثل قرضه، ولا يأخذ فضهالً: لئلا يكون قرضـاً جر منفعةً. ونص الحنفية على أن المدين إذا قضى الدين أجود محا عليه، فلا يجبر ربّ الدين على القبول، كما لو دفع إليه أنقص مما عليه، وإن قبل جاز، كما لو أعطاه خلاف الجنس. قال في الفتاوى الهندية: وهو الصحيح ·.

\footnotetext{
${ }^{6}$ Anas Ibnu Malik al-Mudawanah al-Kubara (Beirut, Dar al-Fikr, 1978),h.341

${ }^{7}$ Al-Sayis, Ali, Nasy' atu al'Fiqh al-Ijtihâd wa Athwâruh, (Kairo, Majma' al-Buhuts alIslamiyah, 1980), hal.33
} 
Sebagaimana yang telah diterangkan, dari bebarapa mazhab fuqha', tentang bentu pengembalian pinjaman tersebut, baik dalam bentuk, maupun nilai, kualitas barang pinjaman tersebut, sedangkan yang berhubungan dengan bagus atau jeleknya barang tersebut digolongkan pada kualitas, kurang dan lebih digolongkan kepada kuantitas, jumhur fuqaha Hanafiah, as-Syafi'iyah, Hanabila dan Ibnu Habib dari mazha Maliki dan ulama lainnya membolehkan kelebihan dalam bentuk apapun baik kualitas maupun kuantitas atas dasar kesepakatan pihak yang melakukan transaksi, selama kedua belah pihak tidak bersepakat untuk melakukan penambahan pengembalian hutang tersebut. ${ }^{8}$ Hal ini sah karena telah dilakukan oleh Rasulullah yang meminjam onta yang berumur tiga tahun dan mengembalikannya dengan yang lebih baik dan beliau barkata sebaik-baik kamu adalah orang yang paling baik dalam membayar hutang, bahkan Syafi'iyah dan Hanafiyah menjadikan hadits tersebut sebagai dasar bahwa sunnah hukumnya bagi orang yang berhutang untuk membayar hutangnya dengan yang lebih baik, tidaklah makruh hukumnya bagi orang yang berpiutang menerimanya. ${ }^{9}$

Imam Malik merincikan masalah ini, makruh hukumnya orang yang berhutang melebihkan pembayarannya dalam kuantitas, kecuali hanya sedikit saja, ihsan yang dimaksudkan itu adalah dengan memberikan kualiatas yang lebih baik, sedangkan melebihkan kuantitas/timbangan dan jumlah tidak diperbolehkan dan ini tanpa ada persyaratan sebelumnya

Dirawikan dari Ahmad ia melarang penambahan dalam pinjaman dalam bentuk apapun baik kualitas maupun kuantitas, diriwayatkan dari Ubay bin Ka'b, Ibnu Abbas, Ibnu Umar, R.A, bahwa orang yang berpiutang menerima piutang sesuai dengan yang dihutangkannya, tidak boleh lebih, supaya pinjaman tersebut tidak mendatangkan manfa'at, Hanafi menjadikan hadits diatas sebagai dalil terhadap orang yang berhutang membayar dengan lebih baik dalam kualitas, janganlah dipaksa urang yang menerima piutang untuk menerimanya, sama halnya apabila hutang itu dibayar dalam keadaan kurang, apabila pihak yang

\footnotetext{
${ }^{8}$ Al-Jashash, Abu Bakar Ahmad Ibn Ali al-Razi, Ahkâm al-Qur'ân, (Beirut: Dār al-Kutub alArabī, t.t. juz 1), hal.331

${ }_{9}^{9}$ Amin, Abdullah bin Syaikh Muhammad, 'Ilâj al-Qur' ân al-Karim li al-Jarîmah, (Madinah: Tp.p., 1982.),hal.34
} 
punya piutang rela maka pembayaran itu diperbolehkan, sama halnya membayar hutang dengan jenis yang lain, hal ini dikatakan dalam sah dalam buku fatwa hindiah. $^{10}$

\section{PEMBAHASAN}

\section{A. Riba dalam Segala Bentuk Haram?}

Apakah setiap riba dalam bentuk apapun pasti diharamkan secara mutlak atas kedua belah pihak (pemberi piutang/rentenir dan yang berhutang)? Ataukah hanya diharamkan atas rentenir saja, sedangkan yang berhutang terbebas? Dan bila yang berhutang tidak berdosa, apakah hal ini hanya bila sedang membutuhkan kepada piutang saja, terjepit dan kemiskinan, ataukah kebutuhan tidak menjadi persyaratan bagi bolehnya berhutang dengan membayar riba? Bila dibolehkan bagi orang yang membutuhkan/terjepit, apakah bagi orang yang kebutuhannya tidak terlalu mendesak boleh untuk berhutang dari bank yang bertransaksi dengan bunga/riba $15 \%$ setiap tahun misalnya-. Dengan demikian, ia dapat berusaha dengan modal uang hutang tersebut, dan menghasilkan keuntungan yang lebih besar dari bunga/riba yang ditetapkan, misalnya keuntungannya sebesar $50 \%$ setiap tahun. Dengan cara ini, berarti ia berhasil memperoleh hasil dari piutang tersebut sebesar $35 \%$ yang merupakan sisa keuntungan dikurangi bunga yang ditetapkan, sebagaimana pada kasus yang dicontohkan, ataukah riba tetap tidak boleh dengan cara apapun?

${ }^{10}$ al-Madany, Muhammad Mawathin al-Ijtihad fi al-Syari' at al-Islamiyah, (Kuwait: Maktabah al-Manar, t.t. ), hal.343 
Riba diharamkan dalam keadaan apapun dan dalam bentuk apapun. Diharamkan atas pemberi piutang dan juga atas orang yang berhutang darinya dengan memberikan bunga, baik yang berhutang itu adalah orang miskin atau orang kaya. Masing-masing dari keduanya menanggung dosa, bahkan keduanya dilaknati (dikutuk). Dan setiap orang yang ikut membantu keduanya, dari penulisnya, saksinya juga dilaknati ${ }^{11}$. Berdasarkan keumuman ayat-ayat dan hadits-hadits shahih yang-nyata mengharamkan riba. Allah Ta'ala berfirman,

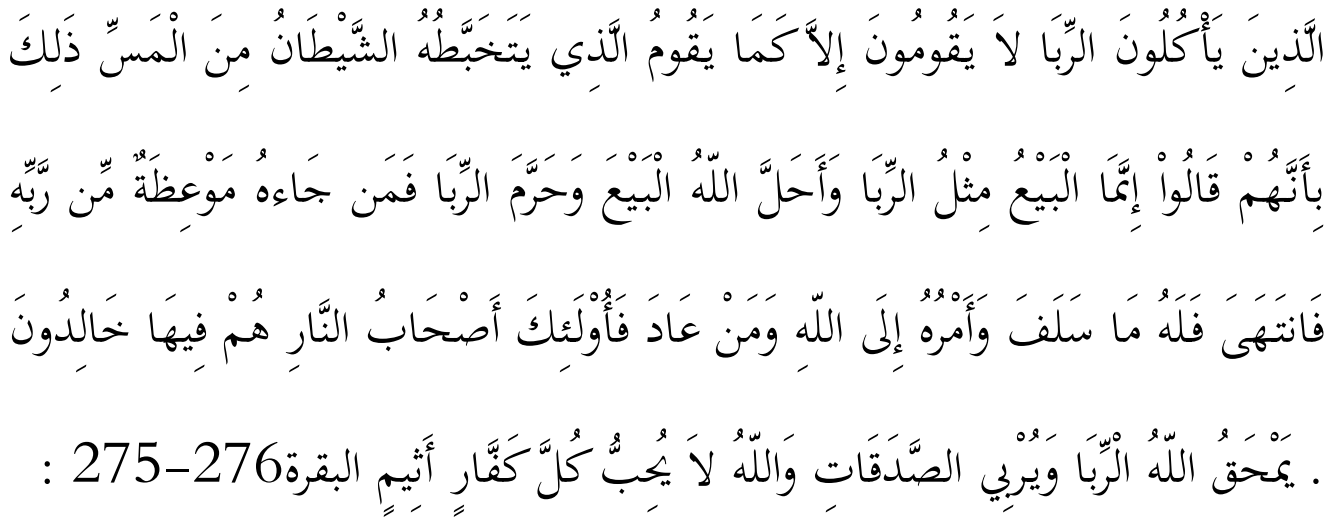

"Orang-orang yang makan (mengambil) riba tidak dapat berdiri melainkan seperti berdirinya orang yang kemasukan syaitan lantaran (tekanan) penyakit gila. Keadaan mereka yang demikian itu disebabkan mereka berkata (berpendapat), sesungguhnya jual beli itu sama dengan riba. Orang-orang yang telah sampai kepadanya larangan dari Rabb-nya, lalu terus berhenti (dari mengambil riba), maka baginya apa yang telah diambilnya dahulu (sebelum datang larangan); dan urusannya (terserah) kepada Allah. Orang

\footnotetext{
${ }^{11}$ M ajmu' F atawa al-Lajnah ad-D a'imah 13/268-271, fatwa no. 3630
} 
yang mengulangi (mengambil riba), maka orang itu adalah penghunipenghuni neraka; mereka kekal di dalamnya. Allah memusnahkan riba dan melipat-gandakan sedekah. Dan Allah tidak menyukai setiap orang yang senantiasa berbuat kekafiran / ingkar, dan selalu berbuat dosa." (Qs. alBaqarah: 275-276).

Sahabat Ubadah bin Shamit radhiallahu 'anhu meriwayatkan dari Nabi shallallahu 'alaihi wa sallam bersabda,

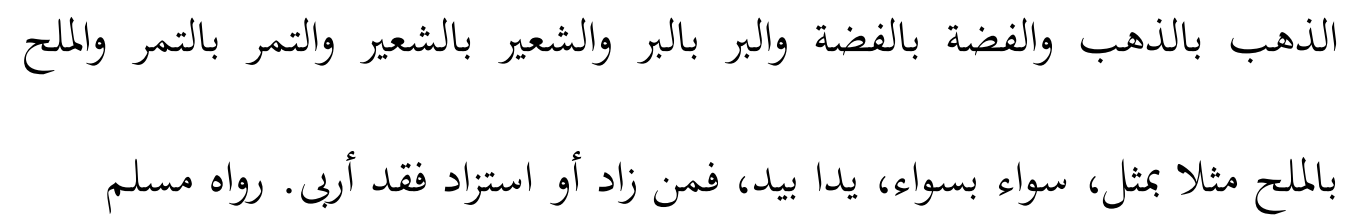

"Emas dijual dengan emas, perak dijual dengan perak, gandum dijual dengan gandum, sya'ir (salah satu jenis gandum) dijual dengan sya'ir, kurma dijual dengan kurma, dan garam dijual dengan garam, (takaran / timbangannya) harus sama dan kontan. Barangsiapa yang menambah atau meminta tambahan, maka ia telah berbuat riba." (HR. Muslim dalam kitabnya asShahih).

Sahabat Abu Sa'id al-Khudri radhiallahu 'anhu menuturkan bahwasannya Nabi shallallahu 'alaihi wa sallam bersabda, 
لا تبيعوا الذهب بالذهب إلا مثلا بمثل، ولا تشفوا بعضها على بعض، ولا تبيعوا الورق بالورق إلا مثلا بمثل، ولا تشفوا بعضها على بعض، ولا تبيعوا منها غائبا بناجز • برواه البخاري ومسلم

"J anganlah engkau jual emas ditukar dengan emas melainkan sama dengan sama, dan janganlah engkau lebihkan sebagiannya di atas sebagian lainnya. Janganlah engkau jual perak ditukar dengan perak melainkan sama dengan sama, dan janganlah engkau lebihkan sebagiannya di atas sebagian lainnya. Dan janganlah engkau jual sebagiannya yang diserahkan dengan kontan ditukar dengan lainnya yang tidak diserahkan dengan kontan." (HR. alBukhary dan Muslim).

Imam Ahmad dan al-Bukhary meriwayatkan, bahwasannya Nabi shallallahu ‘alaihi wa sallam bersabda,

$$
\begin{aligned}
& \text { الذهب بالذهب والفضة بالفضة والبر بالبر والشعير بالشعير والتمر بالتمر والملح } \\
& \text { بالملح مثلا بمثل، سواء بسواء، يدا بيد، فمن زاد أو استزاد فقد أربى، الآخذ } \\
& \text { والمعطي فيه سواء. رواه مسلم }
\end{aligned}
$$

"E mas dijual dengan emas, perak dijual dengan perak, gandum dijual dengan gandum, sya'ir (salah satu jenis gandum) dijual dengan sya'ir, kurma dijual dengan kurma, dan garam dijual dengan garam, harus sama dan sama dan kontan. Barangsiapa yang menambah atau meminta tambahan, maka ia telah 
berbuat riba, pemungut dan yang memberikannya dalam hal ini sama." (HR. Muslim).

Dan telah tetap dari sahabat Jabir bin Abdillah radhiallahu 'anhu bahwasannya ia menuturkan,

لعن رسول الله صلّى الله عليه وسلّم آكل الربا وموكله وكاتبه وشاهديه، وقال: (هم

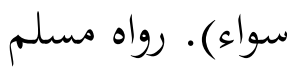

"Rasulullah shallallahu 'alaihi wa sallam telah melaknati pemakan riba (rentenir), orang yang memberikan / membayar riba (nasabah), penulisnya (sekretarisnya), dan juga dua orang saksinya. Dan beliau juga bersabda, 'M ereka itu sama dalam hal dosanya'." (HR. Muslim).

Dan uang kertas yang berlaku pada zaman sekarang ini kedudukannya sama dengan emas dan perak yang berfungsi sebagai alat jual beli, oleh karena itu hukumnya adalah sama dengan hukum emas dan perak. Dengan sebab itulah, hendaknya setiap orang muslim untuk mencukupkan diri dengan hal-hal yang dihalalkan dan menjauhkan dirinya dari segala yang diharamkan Allah 'Azza wa Jalla. Dan Allah sungguh telah memberikan kelapangan kepada umat Islam dalam hal pekerjaan di dunia ini guna mengais rezeki. Sehingga, bisa saja orang yang fakir bekerja sebagai tenaga kerja (kuli) atau pelaku usaha dengan menggunakan modal orang lain dengan sistem mudharabah dengan perjanjian bagi hasil, misalnya fifty-fifty atau yang semisalnya dari keuntungan, dan 
bukan dari modal, tidak juga dengan jumlah / nominal uang tertentu dari keuntungan. Bahkan penggunaan uang logam dan uang kertas lebih rentan untuk praktek riba dengan alas an penurunan nial mata uang maka timbulah bunga sedangkan mereka tidak pernah menyinggung permasalahan kenaikan mata uang atau nilainya sehingga uang para nasabah dikembalikan atau dianggap sebagai hasil surplus dari penguatan mata uang tersebut. Bank manapun diatas dunia ini tidak pernah memberikan keuntungan kepada nasabahnya dengan penguatan mata uang yang disimpannya akan tetapi yang selalu merasakan keurugian akibat melemahnya mata uang yang disimpan bank adalah para nasabah itu sendiri ${ }^{12}$. Dan barang siapa yang tidak mampu berusaha padahal ia fakir, maka halal baginya untuk meminta-minta, menerima zakat, dan juga jaminan sosial.

Tidak boleh bagi seorang muslim, baik kaya atau fakir untuk berhutang kepada bank atau lainnya dengan bunga $5 \%$ atau $15 \%$ atau lebih atau kurang dari itu. Karena itu adalah riba, dan termasuk dosa besar. Dan Allah telah mencukupkan baginya dengan jalan-jalan mengais rezeki yang dihalalkan sebagaimana disebutkan di atas, baik menjadi tenaga kerja di tempat orang yang memiliki pekerjaan atau mendaftarkan diri menjadi pegawai negeri pada jabatan yang halal, atau berdagang dengan modal orang lain dengan sistem

${ }^{12}$ Rifial Ka'bahSeminar Ekonomi Islam, Pps IAIN I.B Padang 5 Agustus 2004 
mudharabah dengan bagi hasil dalam persentase tertentu, sebagaimana dijelaskan di atas. ${ }^{13}$

\section{B. SYUBUHAT-SYUBUHAT SEPUTAR BUNGA BANK}

1. Bunga bank dianggap membalas kebaikan dengan kebaikan yang lebih.

\section{Syubuhat :}

"Saya tidak dapat mengatakan bahwa setiap tambahan terhadap harta pokok dianggap sebagai riba yang diharamkan syari'at, karena beberapa ayat Al Quran dan hadits Rasulullah saw. tidak menguatkan hal itu, bahkan menguatkan seruan untuk menanamkan ruh kemurahan hati dan membalas kebaikan dengan kebaikan yang lebih baik. Dalil :

"Apabila kalian dihormati dengan suatu penghormatan, maka balaslah penghormatan itu dengan yang lebih baik atau balaslah (dengan yang serupa). Sesungguhnya Allah memperhitungkan segala sesuatu." ( Q.S An Nisaa' : 86)

“...Dan janganlah kalian melupakan keutamaan diantara kalian. Sesungguhnya Allah Maha Melihat segala apa yang kalian kerjakan." Q.S Al Baqarah : 237 )

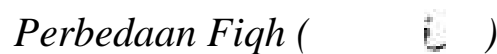

"Memang tidak setiap tambahan terhadap harta pokok dapat dianggap riba. Namun tambahan yang disyaratkan diawal terhadap

\footnotetext{
${ }^{13}$ Nalar Islami dan Nalar Modern: Berbagai Tantangan dan Jalan Baru, (Jakarta: INIS,
} 1994.), hal.146 
uang/harta pokok tanpa ada transaksi pengganti yang dibenarkan syari'at, adalah riba yang diharamkan.

Adapun ayat di atas tidak memuat dalil tentang masalah riba (bunga), baik yang tersirat ataupun yang tersurat, yang zhahir ataupun yang dapat ditakwil. Apakah termasuk mambalas kebaikan ketika peminjam diharuskan membayar pinjaman disertai tambahan (bunga) yang telah ditetapkan, sementara yang memberikan pinjaman tidak peduli dengan kondisi sipeminjam?"

2. Rasulullah pernah membayar utang lebih dari harta pokok yang dipinjam. Dari Abu Rafi' r.a bahwa Rasulullah saw. meminjam unta yang berumur tiga tahun kepada seseorang. Lalu datang unta-unta shadaqah kepada beliau. Beliau memerintahkan Abu Rafi' menyahur unta pinjaman itu. Tapi Abu Rafi' kembali dan berkata :"saya tidak mendapatkan di antara untaunta shadaqah kecuali yang sudah berumur enam tahun.” Beliau bersabda :'Berikan saja kepadanya, karena sebaik-baik manusia ialah yang paling baik penyahurannya di antara mereka."

Jadi orang itu meminjamkan seekor unta yang berumur tiga tahun kepada nabi saw. lalu beliau menggantinya dengan unta yang berumur enam tahun; yang berarti lebih baik dan lebih mahal. Anggaplah unta yang berumur tiga tahun nilainya seribu dirham, sedangkan yang enam tahun nilainya seribu limaratus dirham, apakah tambahan terhadap harta pokok ini juga dianggap riba? 


\section{Jawaban :}

Terdapat perbedaan yang mendasar antara apa yang dilakukan oleh Rasulullah dan apa yang dilakukan oleh bank dewasa ini. Dalam hadits di atas, orang yang memberikan pinjaman tidak menetapkan syarat kepada Nabi saw. agar beliau melunasi unta berumur tiga tahun dengan unta yang berumur enam tahun. Sementara bank menetapkan tambahan dimuka, yang berarti itu riba.

Tentang syarah hadits ini, Imam An Nawawy Rahimahullah mengatakan : "di dalam hadits ini disebutkan bahwa siapa yang mempunyai beban pinjaman berupa al qordhu atau yang lainnya, maka dianjurkan agar dia mengembalikan dengan barang atau pengembalian yang lebih baik dari barang yang dipinjamkan kepadanya. Yang demikian ini hukumnya sunat dan termasuk akhlak yang mulia. Ini bukan merupakan pinjaman yang dimanfaatkan untuk mendapatkan keuntungan, karena yang demikian itu dilarang. Karena yang dilarang ialah jika ada syarat dalam transaksi pinjam meminjam."

Al Hafizh Ibnu Hajar Al 'Asqolani berkata ;" di dalam hadits ini terkandung pembolehan mengembalikan yang lebih baik dari pinjaman, jika tidak ada syarat. Jika syarat itu terjadi dalam transaksi, maka hal itu haram menurut kesepakatan. Ini juga merupakan pendapat jumhur." Jadi Nabi saw. mengembalikan pinjaman lebih banyak/baik dari pinjaman, tanpa ada syarat atau kesepakatan di antara keduanya. Adapun bank konvensional, ketika seseorang menabung satu juta rupiah, maka dia 
membuat kesepakatan dengan pihak bank bahwa uangnya akan bertambah $12 \%$ misalnya, setiap tahun. Kemudian datang orang lain untuk mendapatkan pinjaman dari bank, lalu pihak bank menyetujui pinjaman itu, tapi dengan syarat nasabah yang menjadi debitur harus mengembalikan pinjaman dengan tambahan $17 \%$ untuk jangka waktu satu tahun. Disini ada penetapan syarat saat terjadi transaksi tabungan dari nasabah dan saat memberikan pinjaman dengan nasabah lain, sehingga bank melakukan praktik riba dua kali.

Dari Nafi', bahwa ia pernah mendengar Abdullah bin Umar berkata , 'Barang siapa meminjamkan suatu pinjaman, maka dia tidak boleh menetapkan syarat kecuali pelunasan pinjaman itu.' Ibnu Qudamah berkata Setiap pinjaman yang didalamnya ada penetapan syarat tambahan, maka hal itu haram tanpa ada perselisihan pendapat tentang hal itu' ${ }^{14}$

3. Masalah rela sama rela (saling ridho).

Telah ada ketetapan dalil-dalil yang shahih dalam Al Kitab dan As Sunnah serta ijma' bahwa tambahan yang disyaratkan terhadap harta pokok ketika terjadi transaksi pinjam-meminjam, dianggap riba yang diharamkan menurut syari'at. Jika sesuatu sudah ada ketetapan pengharamannya menurut syari'at, maka tidak dapat dibuat halal karena ada saling ridha.

\footnotetext{
${ }^{14}$ dalam kitab al Mughny, jilid 6 hal.436
} 
Umpanya ada seorang laki-laki berzina dengan wanita, keduanya saling ridho dan suka sama suka. Apakah zina itu menjadi halal bagi keduanya ? Atau ada seorang laki-laki menikah dengan saudari kandungnya, keduanya saling ridha. Apakah pernikahan ini sah?

4. Bunga bank boleh untuk kemaslahatan manusia.

Ini merupakan pernyataan yang tidak masuk akal, karena apakah mungkin pertimbangan kemaslahatan manusia dapat menghalalkan sesuatu yang telah jelas haram menurut syari'at? Bagaimana mungkin pertimbangan kemaslahatan manusia dapat membuat riba sebagai sesuatu yang halal bagi orang yang memakannya, wakilnya, sekretarisnya dan kedua saksinya, meskipun Nabi saw. telah melaknat orang-orang itu?

Contoh : Negara memerlukan pendapatan dalam rangka mengangkat taraf hidup. Potensi kelautan memiliki peranan yang sangat besar untuk meningkatkan pendapatan negara. Sementara para pelaut asing dari kalangan orang-orang kafir dan musyrik tidak dapat bekerja secara optimal kecualai jika mereka minum arak. Lalu apakah kita harus membolehkan produksi arak, menjual dan memperdagangkannya serta menyuguhkannya kepada para nelayan atau pelaut? Tidak, Tidak boleh. Yang haram tetap saja haram.

5. Kekeliruan menggolongkan bunga bank kepada wakalah.

Transaksi dengan bank tidak dapat disebut wakalah, karena syarat-syarat wakalah tidak cocok untuk transaksi dengan bank. Diantaranya : pertama, al wakil maupun al muwakil tidak boleh menetapkan syarat nilai dimuka 
dari harta pokok. Sekiranya al wakil dan al muwakkil menyalahi syarat ini, lalu keduanya menetapkan syarat nilai dimuka, maka al wakalah menjadi gugur dan ia berubah menjadi hutang piutang ribawi yang diharamkan.

Syarat kedua, al wakil tidak dapat memberi jaminan sekiranya barang yang didelegasikan rusak, tanpa ada tindakan pengabaian darinya. Sementara bank memberikan jaminan terhadap hal tersebut. Sekiranya seseorang menyimpan uangnya di bank sejumlah satu juta rupiah, lalu uang itu dipergunakan bank untuk membangun pabrik, tapi pabrik yang sudah dibangun terbakar tanpa ada kesengajaan atau tanpa ada pengabaian dari bank, maka apa sikap nasabah? Tentu dia akan menuntu haknya secara penuh dan juga dengan tambahan yang telah disepakati dimuka.

6. Kegiatan usaha Bank Konvensional bukan Mudharabah

Diantara alasan nyeleneh dan kontroversial yang dikemukakan oleh sebagian orang yang ingin menjustifikasi bunga riba itu ialah bahwa bunga itu merupakan bagian keuntungan bagi pejabat di lingkungan bank Konvensional. Hal ini untukmenggambarkan bahwa praktik yang dilakukan bank itu identik dengan mudharabah (prinsip bagi hasil) Maksudnya, dalam hubungan antara pihak bank dengan pihak nasabah, bank berfungsi sebagai mudharib 'yang akan mengusahakan harta dan mengembangkannya', dan nasabah berkedudukan sebagai pemilik harta (financier). Kemudian dalam hubungan antra pihak bank dengan pihak 
ketiga, bank berfungsi sebagai pemilik harta, sementara pihak ketiga berfungsi sebagai mudharib.

Gambaran di atas bertentangan dengan inti kontrak mudharabah. Karena dalam akad tersebut posisi mudharib adalah sebagai pemegang amanah terhadap harta yang diserahkan kepadanya, bukan sebagai penjamin. Jadi pihaknya tidak bertanggung jawab atas kehilangan/kerusakan kecuali terbukti bahwa ia telah melakukan pengkhianatan, pelanggaran atau menyepelekannya.

Seandainya dimasukkan dalam persyaratan bahwa mudharib menjamin keselamatan uang/harta mudharabah maka akan mengakibatkan batalnya akad mudharabah dan hilang legalitasnya. Sedangkan fakta yang tidak mungkin dibantah kebenarannya bahwa bank menjamin uang yang dipegangnya. Bagaimana mungkin bank dalam hal ini berfungsi ganda sebagai pemegang amanah dan sebagai penjamin dalam waktu yang sama?

Demikan pula dalam akad mudharabah diisyaratkan kedudukan yang seimbang antara keduabelah pihak dalam menanggung resiko baik untung maupun rugi. Tidak boleh secara sepihak mendapat keuntungan yang pasti dari sejumlah uang tertentu dengan mengorbankan pihak lain. ${ }^{15}$ Penentuan jumlah nominal uang atau harta tertentu dikhususkan untuk pemilik modal saja, ataupun khusus untuk mudharib, mengakibatkan rusaknya akad mudharabah dan bergeser dari lingkungan halal ke

15 al-Zarqani, Muhammad Abd al-Azim Manâhil al-Irfân fi Ulum al-Qurân, (Mesir: Isa alBābi al-Halabi, 1957),hal.234 
lingkungan haram. Ibnu M undzir berkata, 'seluruh ahli ilmu pengetahuan islambersepakat atas batalnya akad mudharabah jika salah satu pihak atau masing-masing pihak menentukan persyaratan khusus beberapa dirham tertentu untuk dirinya'. Ibnu Qudamah mengatakan bahwa hal itu tidak sah karena dua alasan ${ }^{16}$ :

a. Sekiranya ia syaratkan nominal tertentu yang akan menjadi haknya, berkemungkinan hanya jumlah nominal itu yang menraik keuntungan. Akibatnya, hanya pihaknya yang menguasai seluruh keuntungan atau sebaliknya, jumlah nominal itu tidak menghasilkan apa-apa sehingga ia tidak mendapatkan apa-apa atau ia untung besar sehingga ia dirugikan.

b. Bagian (porsi) seharusnya diketahui dalam bentuk pembagian (persentase), karena tidak mungkin menentukan jumlahnya secara pasti. Jika pembagian itu tidak diketahui oleh masing-masing pihak, maka kontrak tersebut menjadi bata(rusak)

7. Masalah riba yang berlipat ganda.

Dalam upaya untuk mencari-cari celah membolehkan bunga bank, ada orang yang beralasan bahwa riba yang diharamkan Al Qur'an ialah riba yang adh'afan mudha' afah'berlipat ganda', sedangkan riba yang kecil seperti $8 \%$ atau $10 \%$ tidak termasuk riba yang dilarang. Ungkapan ini terdengar sejak awal abad kedua puluh, dengan alasan berpegang kepada konotasi ayat Al Qur'an :

\footnotetext{
${ }^{16}$ Ibnu Qudama al M ughny, jilid 6 hal.436 ,
} 
"Wahai orang-orang yang beriman, janganlah kamu memakan riba dengan berlipat ganda, takutilah Allah, semoga kamu beruntung." (Q.S Ali Imran : 130)

Orang yang memiliki kemampuan memahami cita rasa bahasa Arab yang tinggi dan mnemahami retorikanya, sangat memaklumi bahwa sifat riba yang disebutkan dalam ayat ini 'adh'afan mudha'afah' adalah dalam konteks menerangkan kondisi objektif dan sekaligus mengecamnya. Mereka telah sampai pada tingkat ini dengan cara melipatgandakan bunganya $^{17}$.

Pola berlipat ganda ini tidak dianggap sebagai kriteria (syarat) dalam pelarangan riba. Dalam arti bahwa berlipat ganda hukumnya boleh. Lagi pula manakah yang disebut disebut riba yang kecil dan mana riba yang besar? Siapa yang menyatakan $10 \%$ itu kecil dan $12 \%$ itu besar? Apa ukurannya? Sangat relatif. Jika kita mau berpegang pada makna eksplisit ayat, maka yang disebut berlipat ganda itu besarnya $600 \%$ sebagaimana yang pernah diungkapkan oleh Prof. Dr.Muhammad Daraz, karena kata 'adh'af' itu sendiri bentuk jamak, paling sedikitnya tiga. Maka, jika tiga dilipatgandakan walaupun sekali, maka akan menjadi enam. Adakah yang membenarkan hal ini?

Dalam surah Al Baqarah, terdapat penghapusan riba secara total.

"Wahai orang-orang yang beriman, takutlah kepada Allah dantinggalkanlah sisa riba, jika kamu orang yang beriman. Jika kamu tidak melepaskan seluruh sisa riba, maka ketahuilah bahwa Allah dan Rasul-Nya akan memerangimu. Jika

\footnotetext{
${ }^{17}$ Yusuf Qaradawi Riba Haram,
} 
kamu bertobat, maka bagimu pokok hartamu. Kamu tidak menganiaya dan tidak pula dianiya." ( Q.S Al Baqarah : 278-279 )

\section{KESIMPULAN}

Sesungguhnya akad pinjaman untuk menolong seseorang dalam kehidupannya dan bukanlah pinjam meminjam ini termasuk sebuah usaha yang menghasilkan atau tempat menghasilkan keuntungan bagi seseorang. Dan bukan pula pinjam meminjam ini sebagai media eksploitasi terhadap sebagian orang atas sebagian yang lain. Oleh karena itu orang yang meminjam uang tidak mengembalikan pinjamannya kecuali sesuai dengan apa yang dipinjamkan pertama kali sesuai dengan kaidah fiqh yang dikatakan oleh para fuqaha

setiap pinjaman yang terdapat manfaat dalamnya maka ia adalah riba ${ }^{18}$. Akan tetapi keharaman riba itu terikat dengan akad yang dilakukan pertama kali atau merujuk kepada persyaratan yang dikemukakan waktu akad tersebut berlangsung. Apabila tidak ada persyaratan untuk menambah jumlah pengembalian atau kesepakatan sebelumnya. Apabila persaratan dan kesepakatan tidak ada sebelumnya maka apabila pinjaman tersebut bertambah atau diganti dengan yang lebih baik dikemudian hari maka itu bukanlah riba namanya. Bagi orang yang meminjamkan boleh mengambilnya tanpa ada sangsi apapun dan tidak dianggap telah berbuat perkara yang makruh.

Hal in berdasarkan hadits yang dirawikan dari Rasulullah S.A.W dari Abi Rafi'

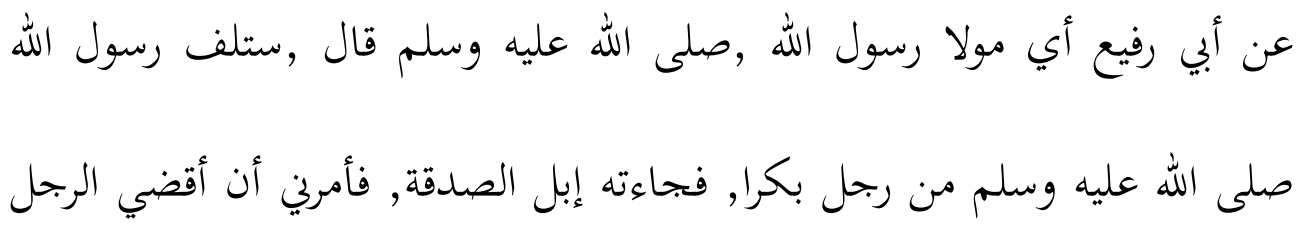

\footnotetext{
${ }^{18}$ Sayid Sabiq Fiqh Sunnah (Beirut;Dar al-Fikr, 1992),Jilid III, h.184
} 


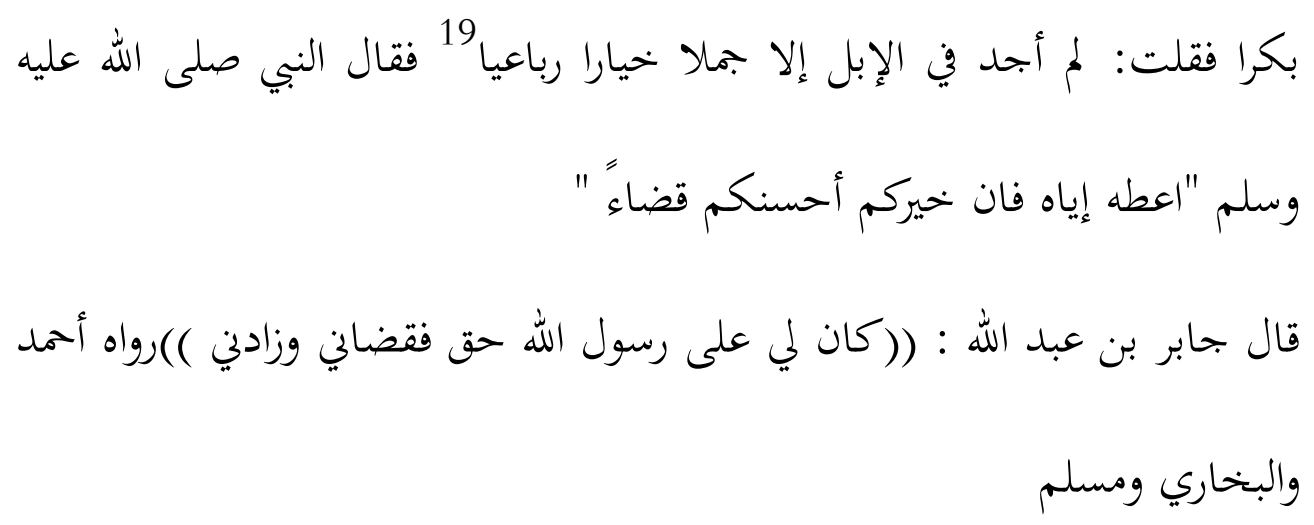

Dari Abi Rafi' hamba Rasulullah S.A.W berkata," Rasulullah meminjam seekor berumur tiga tahun, kemudian datang kepada Rasulullah ontah dari hasil sedekah (Zakat), dan ia meminta saya (Abi Rafi') untuk membayar dengan onta yang berumur tiga tahun, akan tetapi saya tidak mendapatkan onta yang sepadan hanya ada seekor onta yang telah berumur 6 tahun (akan memasuki umur 7 tahun), berkata Nabi S.A.W "berikanlah kepada orang itu, sebaik-baik kamu adalah orang yang paling baik dalam membayar hutang!".

\section{DAFTAR PUSTAKA}

Al-Qur' an al-Karim,KSA, 2006

Anas Ibnu Malik al-Mudawanah al-Kubara (Beirut, Dar al-Fikr, 1978)

Sayid Sabiq Fiqh Sunnah, (Dar al-Fikr, 1990)

Ali Hafif at-Ta'min Majma' Buhuts Islamiah (Kairo, Dar Tsaqafah, 2016), h.617

Al-Juwaini, al-Burhan fi Ushul al-Fiqh (Kairo, Dar al-Wafa, 1988)

Al-Arabi, Muhammad bin Abdullah al-Qabs Syarah Muwatha Malik (Rabath, Dar al-Gharb al-Islam, 2016)

Al-Wakil, Muhammad bin Umar, al-Asybah wa an-Nazair bi Tahqiq (Kairo, Maktabar Rasyid, 1999)

Abu Yusuf, Kitâb al-Kharâj, Kairo: Al-Matba'ah al-Salafiah, 1962/ 1963.

الخيار:المختار, و الرباعي الذي استكمل ست سنين ودخل في السابعة'19 
Abu Zahrah, Ushul al-Fiqh, Beirut: Dar al-Fikr, tt, .

Albert Hourani, A History of the Arab Peoples, Cambridge, Massachusetts: The BelknapPress of Harvard University Press, 1991.

Al-Ghazali, Al-Mustashfâ fî Ilmi al-Ushûl, Beirut: Dār al-Kutub al-Ilmiyah, 1993. al-Jashash, Abu Bakar Ahmad Ibn Ali al-Razi, Ahkâm al-Qur’ân, Beirut: Dār alKutub al-Arabī, t.t. juz 1.

al-Kahlani, Muhammad Ibn Ismail, Subul al-Salâm Syarah Bulûgh al-Marâm, Beirut: Dār 1-Fikr, t.t. juz 3.

al-Madany, Muhammad Mawathin al-Ijtihad fi al-Syari'at al-Islamiyah, Kuwait: Maktabah al-Manar, t.t.

Al-Maraghi, Ahmad Musthafa, Tafsîr al-Maraghî, Mesir: Al-Halabi, 1946. Jilid I,al-Nabhani, Taqiyuddin, Nizham al-Hukmi fi al-Islam, Beirut: Dar alUmmah, $410 \mathrm{H}$.

al-Qardhawi, Yusuf, Al-Madkhâl fi Dirâsât al-Syari' at al-Islâmiyat, Ed. Indonesia, Membumikan Syariat Islam, Surabaya: Dunia Ilmu, 1997.

al-Qaththan, Manna', Mabâhits fî̀ 'Ulum al-Qru’ân, Riyad: 1973.

Al-Sayis, Ali, Nasy'atu al'Fiqh al-Ijtihâd wa Athwâruh, Majma' al-Buhuts alIslamiyah, 1980.

Al-Syathibi, Al-Muwâfaqât fî̀ Ushûl al-Ahkâm, Mesir: Dār al-Fikr, t.t.

Alwi Shihab, Islam Inklusif, Menuju Sikap Terbuka dalam Beragama, Bandung: Mizan, 1997.

al-Zarqani, Muhammad Abd al-Azim Manâhil al-Irfân fi Ulum al-Qurân, Mesir: Isa al-Bābi al-Halabi, 1957.

Al-Zuhaili, Wahbah Al-Fiqh al-Islâmi wa Adillatuh, Suriah: Dār al-Fikri, Cet. 4, 1997.

Ushûl al-Fiqh al-Islâmi, Beirut: Dâr al-Fikri, 1986.

Amin, Abdullah bin Syaikh Muhammad, 'Ilâj al-Qur'ân al-Karim li al-Jarîmah, Madinah: Tp.p., 1982.

An-Na'im, Toward an Islamic Reformation: Civil Liberties, Human 
Rights, and International LawNewYork: Syracuse University Press, 2016

Arkoun, Mohammad, Berbagai Cara Pembacaan Quran, Jakarta: INIS, 1997.

Nalar Islami dan Nalar Modern: Berbagai Tantangan dan Jalan Baru, Jakarta: INIS, 1994.

Arnold J. Toynbe, A Study of Histori I-IV, New York \& London: Oxford University Press, 1946.

Azra, Azyumardi, Jaringan Ulama: Melacak Akar-akar Pembaharuan Pemikiran Islam di Indonesia, Bandung: Mizan, 1994.

Dr.Yaqub ibnu Abdul Wahab al-Bahisin, al-Furuq Fiqhiyah wa alUshuliyah,Riyadh, (Syirkah Riyadh li at-Tawzi',1998)

Sahih Muslim Jilid 2 hadits no 1224, Beirut, Dar-Fikr 1992

Imam Faqih al-Qadhiy Abi Muhammad Abdul Wahab bin Ali bin Nasr alBaghdadi Furuq al-Fiqhiyah (Riyadh:Dar al-Buhuts li ad-Dirasat alIslamiyah wa Ihya' at- Turats:1992)

Majmu' Fatawa al-Lajnah ad-Da'imah 13/268-271, fatwa no. 3630 (Kairo, Dar at - Turats al-Arabi)

Ibnu Qudamah Al-Mughni , Kairo, Dat at-Turats al-Arabi, 1991

Wahbah Zuhaili Fiqh Islam wa Adilathu, Beirut, Dar al-Fikr, 1992

Yusuf Qardhawi, Riba Haram, terjemahan, Jakarta, Rabbani Press 1990 